Notes

\title{
HOW THE SPENDING CLAUSE CAN SOLVE THE DILEMMA OF STATE SOVEREIGN IMMUNITY FROM INTELLECTUAL PROPERTY SUITS
}

\author{
JENNIFER COTNER
}

\section{INTRODUCTION}

The United States Supreme Court held in two cases, Florida Prepaid Postsecondary Education Expense Board v. College Savings Bank ("Florida Prepaid") 1 and College Savings Bank v. Florida Prepaid Postsecondary Education Expense Board ("College Savings Bank"), ${ }^{2}$ that states' Eleventh Amendment immunity from patent and trademark infringement suits was not waived or properly abrogated by Congress. ${ }^{3}$ After these decisions were handed down, Congress almost immediately announced hearings to determine what kind of legislation could sidestep these holdings. ${ }^{4}$ Congress realized that allowing states to have immunity from intellectual property infringement actions could have devastating effects on the intellectual property system. The former Register of Copyrights, Barbara Ringer,

Copyright $(2) 2001$ by Jennifer Cotner.

1. 527 U.S. 627 (1999).

2. 527 U.S. 666 (1999).

3. While the Supreme Court has not decided the question specifically, there is every reason to believe that copyright infringement actions would be subject to the same fate. After Florida Prepaid and College Savings Bank, the Fifth Circuit held that states were immune from copyright infringement actions in Chavez v. Arte Publico Press, 204 F.3d 601, 607 (2000).

4. State Sovereign Immunity and Protection of Intellectual Property: Hearings Before the Subcomm. on Courts and Intellectual Property of the House Comm. on the Judiciary, 106th Cong. 1 (2000) (statements of Marybeth Peters, Register of Copyrights; Daniel J. Meltzer, Professor of Law, Harvard Law School; Mark A. Lemley, Professor of Law, University of California at Berkeley; Howard Coble, Chair, House Subcomm. on Courts and Intellectual Property) [hereinafter Hearings on State Sovereign Immunity]; 145 CONG. REC. S10359 (daily ed. Aug. 5, 1999) (statement of Sen. Specter). 
testified before Congress over ten years ago to the breadth of state usage of copyrighted materials:

States and their instrumentalities are major users of copyrighted material of all sorts-not only the familiar forms of printed books and periodicals but the whole range of creative expression ... dance and drama, music and sound recordings; photographs and filmstrips; motion pictures and video recordings; computer software and chips; pictorial and graphic material, maps and architectural plans, and so forth, ad infinitum. State exploitation of copyrighted works is by no means limited to uses that can be called educational or nonprofit. They include large publishing enterprises, computer networks, offair taping, public performance and display, radio and television broadcasting, and cable transmissions, to name only the most obvious.

After Florida Prepaid and College Savings Bank, states are free in essence to exploit these kinds of materials anytime they wish. The intellectual property issue is a pressing one, and Congress must act to remedy the situation immediately. ${ }^{6}$

Following a brief discussion of the legal background, this Note explores the alternatives presently open to Congress and concludes that Congress's best option is to pass a measure that would condition the states' receipt of federal intellectual property rights on their waiver of immunity in infringement actions against them. This "conditional waiver" proposal would encourage individual states to waive their sovereign immunity voluntarily. Under this system, no state would be able to acquire a federal intellectual property right unless it agreed to waive its sovereign immunity from future intellectual property suits.

Two recent articles suggest that this kind of bill would not be constitutional in light of recent Supreme Court decisions that have expanded the state governments' power at the expense of the federal government. ${ }^{7}$ However, as this Note demonstrates, the conditional

5. Copyright Remedy Clarification Act: Hearings on H.R. 1131 Before the Subcomm. on Courts, Intellectual Property and the Admin. of Justice of the House Comm. on the Judiciary, 101st Cong. 93 (1989) (statement of Barbara Ringer, Former Register of Copyrights).

6. See, e.g., Hearings on State Sovereign Immunity, supra note 4, at 24 (statement of Marybeth Peters) (" $[\mathrm{I}] \mathrm{t}$ is important that. ... [Congress] decides to redress the imbalance created by the recent decisions of the Supreme Court. . . . Let me make it clear that I believe Congress should act.").

7. Mitchell N. Berman et al., State Accountability for Violations of Intellectual Property Rights: How to "Fix" Florida Prepaid (And How Not To), 79 TEX. L. REV. 1037, 1147, 1151-55 
waiver bill has the best chance of passing constitutional muster. It will be the most effective means to accomplish Congress's goal-to make states responsible for their acts of infringement just like everyone else. ${ }^{8}$

\section{THE ELEVENTH AMENDMENT AND ITS LOOPHOLES}

The Eleventh Amendment states, "The Judicial power of the United States shall not be construed to extend to any suit in law or equity, commenced or prosecuted against one of the United States by Citizens of another State, or by Citizens or Subjects of any Foreign State." "The Supreme Court effectively has extended the breadth of

(2001) (arguing that a conditional waiver scheme such as this one would fail under the normal test, pronounced by Justice O'Connor in her dissent in Dole, and under a Nollan/Dolan-type test like that used in Fifth Amendment exactions cases); John T. Cross, Suing the States for Copyright Infringement, 39 BRANDEIS L.J. 337, 386 (2000) (arguing that a conditional waiver plan would be unconstitutional because it imposes an unconstitutional condition on the states).

In addition to the cases mentioned infra Part II, the Supreme Court has curtailed congressional power in several other areas. For instance, in 1995, it set limits on Congress's power to legislate under the Interstate Commerce Clause. United States v. Lopez, 514 U.S. 549 (1995). At one point, the Supreme Court looked for only a reasonable and legitimate connection between legislation enacted under the Interstate Commerce Clause and the ends desired, and exhibited extreme deference to congressional findings. See, e.g., Hodel v. Va. Surface Mining \& Reclamation Ass'n, 452 U.S. 264, 276 (1981) (upholding the Surface Mining Control and Reclamation Act as valid under the Commerce Clause because coal moves in interstate commerce and mining influences other resources that affect interstate commerce); Maryland v. Wirtz, 392 U.S. 183, 185-88 (1968) (upholding the Fair Labor Standards Act, which expanded minimum wage and maximum hours coverage of employees engaged in interstate commerce). Lopez requires a tighter fit between means and ends and a substantial nexus between the regulated activity and interstate commerce. See 514 U.S. at 559. The Rehnquist Court also has seriously limited the power of Congress to regulate the states directly. Congress may not "commandeer" state regulatory agencies and legislatures by forcing them to regulate on behalf of Congress. Printz v. United States, 521 U.S. 898, 935 (1997); New York v. United States, 505 U.S. 144, 168 (1992).

8. For an example of the type of bill this Note proposes, see Senate Bill 1835, introduced by Senator Patrick Leahy (D-VT). S. 1835, 106th Cong. (1999). Senator Leahy introduced this legislation less than six months after the Florida Prepaid and College Savings Bank decisions were handed down. S. 1835 also contains a Fourteenth Amendment abrogation proposal that is extremely questionable as an effective means of subjecting states to liability for their acts of infringement. $I d$.

9. U.S. CONST. amend. XI. This amendment effectively overruled Chisholm v. Georgia, in which the Supreme Court had held that a state could be sued by a citizen of another state in federal court. 2 U.S. (2 Dall.) 419, 479-80 (1793). Justice Iredell's dissent in that case provided the blueprint for the Eleventh Amendment. Seminole Tribe v. Florida, 517 U.S. 44, 76 (1996) (Stevens, J., dissenting). Justice Iredell reasoned that in light of the limits on federal court jurisdiction set out in the Judiciary Act (that it should accord with "the principles and usages of law"), federal jurisdiction should be interpreted in light of prevailing common law, which encompassed the sovereign immunity doctrine. Chisholm, 2 U.S. (2 Dall.) at 434-46 (Iredell, J., 
the amendment, holding that States are protected not only from suits initiated by citizens of other states, but also from suits by citizens of the defendant state in federal court. ${ }^{10}$

Presently, a potential plaintiff may circumvent the Eleventh Amendment using only three mechanisms. ${ }^{11}$ The plaintiff may argue that the state waived its immunity; ${ }^{12}$ that Congress abrogated the state's sovereign immunity; or that a state official may be sued under the Ex Parte Young doctrine. ${ }^{13}$ To subject states to intellectual property lawsuits, Congress must use one of these mechanisms.

To determine whether Congress validly has abrogated state sovereign immunity, a court asks "whether Congress has 'unequivocally expresse[d] its intent to abrogate the immunity'... and second, whether Congress has acted 'pursuant to a valid exercise of power.",14 Congress may abrogate state sovereign immunity only by using its enforcement power under Section 5 of the Fourteenth Amendment, ${ }^{15}$ or (probably) any other post-Eleventh Amendment enforcement power. ${ }^{16}$ The strict test announced in City of Boerne v. Flo-

dissenting). He concluded that the language of Article III of the United States Constitution did not change the common law. Id.

10. Hans v. Louisiana, 134 U.S. 1, 15 (1890). The holding in Hans has been criticized by many observers, including Supreme Court Justices, into very recent times. For instance, Justice Stevens has argued that there are in reality two Eleventh Amendments, the one ratified in 1795 and the other invented by the Supreme Court in Hans. Pennsylvania v. Union Gas Co., 491 U.S. 1, 23 (1989) (Stevens, J., concurring). Justice Souter also has expressed his belief, along with Justices Ginsburg and Breyer, that the court in Hans misread the Eleventh Amendment. Seminole Tribe, 517 U.S. at 130 (Souter, J., dissenting).

11. ERWIN CHEMERINSKY, FEDERAL JURISDICTION 389 (3d ed. 1999).

12. The Register of Copyrights, however, in her testimony before Congress, cited a Congressional Research Service report appended to the 1988 Copyright Office study called "Copyright Liability of States and the Eleventh Amendment" that demonstrated few states have waived their immunity from copyright infringement suits in federal court. Hearings on State Sovereign Immunity, supra note 4, at 23 (statement of Marybeth Peters).

13. Chemerinsky, supra note 11, at 389; Nathan C. Thomas, Note, The Withering Doctrine of Ex Parte Young, 83 CoRnell L. REV. 1068, 1076 (1998). The Ex Parte Young doctrine is discussed infra notes 51-59 and accompanying text.

14. Seminole Tribe, 517 U.S. at 55 (quoting Green v. Mansour, 474 U.S. 64, 68 (1985)).

15. Fla. Prepaid Postsecondary Educ. Expense Bd. v. Coll. Sav. Bank, 527 U.S. 627, 636-37 (1999); Seminole Tribe, 517 U.S. at 73. The Court held that Congress may abrogate state immunity by using Section 5 of the Fourteenth Amendment in Fitzpatrick v. Bitzer, 427 U.S. 445, 456 (1976) (holding that the Eleventh Amendment did not bar an award of attorney's fees against a state in a case brought under the Civil Rights Act of 1964 because that Act was enacted under Section 5 of the Fourteenth Amendment).

16. In Seminole Tribe, the Court settled that Congress may not abrogate state sovereign immunity using its Article I powers. 517 U.S. at 73. However, the Fourteenth Amendment is special; it was enacted after the Eleventh Amendment. Section 5 of the Fourteenth Amendment, 
$r e s^{17}$ for whether a particular act of Congress is properly grounded in the Fourteenth Amendment is whether there is "a congruence and proportionality between the injury to be prevented or remedied and the means adopted to that end."

Even if Congress did not abrogate state sovereign immunity, a state still may waive its sovereign immunity by consenting to suit. ${ }^{19}$ That waiver must be voluntary, however, ${ }^{20}$ and the test for determining whether a state has waived its immunity voluntarily is a stringent one. ${ }^{21}$ Courts find a waiver only when the state voluntarily invokes federal court jurisdiction, ${ }^{22}$ or makes a "clear declaration" or an "unequivocal expression" that it intends to consent to federal court jurisdiction. ${ }^{23}$

\section{FLORIDA PREPAID AND COLLEGE SAVINGS BANK}

This Part explores the Supreme Court's decisions in Florida Prepaid and College Savings Bank, in which the Court held that Congress may not abrogate state sovereign immunity in patent and trademark infringement cases, respectively. The parties were the same in each case. College Savings Bank, a private New Jersey bank, developed and sold patented certificates of deposit, which were annuity contracts designed to guarantee investors returns sufficient to fund col-

unlike Article I, gives Congress authority to restrict state power when it infringes on the guarantees provided by that Amendment. Fitzpatrick, 427 U.S. at 456.

17. 521 U.S. 507 (1997).

18. Id. at 520. Congress has the power to enforce the provisions of the Fourteenth Amendment but not to determine what a constitutional violation is. Id. at 519. The Court has long acknowledged that Congress's power under Section 5 is remedial, not substantive. Id. at 520; South Carolina v. Katzenbach, 383 U.S. 301, 326 (1966). Congress may use its Section 5 power to enforce existing constitutional violations, but it may not use this power to define new constitutional violations. City of Boerne, 521 U.S. at 519. It must specifically identify conduct violating the Fourteenth Amendment and narrowly tailor its statute to remedy such conduct. Id.

19. Clark v. Barnard, 108 U.S. 436, 447 (1883).

20. Coll. Sav. Bank v. Fla. Prepaid Postsecondary Educ. Expense Bd., 527 U.S. 666, 675 (1999) (citing Beers ex rel. Platenius v. Arkansas, 61 U.S. (20 How.) 527, 529 (1858)).

21. Atascadero State Hosp. v. Scanlon, 473 U.S. 234, 241 (1985).

22. Gunter v. Atl. Coast Line R.R. Co., 200 U.S. 273, 284 (1906).

23. Pennhurst State Sch. \& Hosp. v. Halderman, 465 U.S. 89, 99 (1984); Great N. Life Ins. Co. v. Read, 322 U.S. 47, 54 (1944). A state does not waive its immunity to suit in federal court by consenting to suit in state court, Smith v. Reeves, 178 U.S. 436, 441-45 (1900), by stating a general intent "to sue or be sued," Fla. Dep't of Health \& Rehab. Servs. v. Fla. Nursing Home Ass'n, 450 U.S. 147, 149-50 (1981) (per curiam), or by generally authorizing suit "in any court of competent jurisdiction," Entergy, Ark., Inc. v. Nebraska, 210 F.3d 887, 897 (8th Cir. 2000) (quoting Kennecott Copper Corp. v. State Tax Comm'n, 327 U.S. 573, 578 (1946)). 
lege tuition. ${ }^{24}$ The Florida Prepaid Board was a state entity that provided an identical annuity contract. ${ }^{25}$

In Florida Prepaid, College Savings Bank initiated a patent infringement action against Florida Prepaid for its use of College Savings Bank's annuity contract. ${ }^{26}$ The Supreme Court granted certiorari after the United States Court of Appeals for the Federal Circuit affirmed the trial court's holding. The trial court had determined that Florida Prepaid was not entitled to immunity under the Eleventh Amendment for the alleged patent infringement because Congress had properly abrogated its immunity using its power under Section 5 of the Fourteenth Amendment. ${ }^{27}$

The Supreme Court found first that the Patent Remedy Act clearly expressed Congress's intent to abrogate state sovereign immunity in patent infringement actions. ${ }^{28}$ Next, the Court considered whether Congress acted legitimately pursuant to an enumerated power. ${ }^{29}$ The legislative history demonstrated that Congress justified the Patent Remedy Act with three constitutional provisions: the Patent Clause,,$^{30}$ the Interstate Commerce Clause, ${ }^{31}$ and Section 5 of the Fourteenth Amendment. ${ }^{32}$ The Court in Seminole Tribe v. Florida held that Article I is not a valid basis for abrogating state sovereign immunity. ${ }^{33}$ Following this line of reasoning, the Florida Prepaid Court concluded that Seminole Tribe effectively barred the first two sources as legitimate justifications for the Patent Remedy Act, because they depended on constitutional powers created before the Eleventh Amendment was enacted. ${ }^{34}$

24. Fla. Prepaid Postsecondary Educ. Expense Bd. v. Coll. Sav. Bank, 527 U.S. 627, 630-31 (1999).

25. Id. at 631 .

26. $I d$.

27. Id. at 634 .

28. Id. at 635 .

29. Id. at 635-36.

30. U.S. CONST. art. I, § 8, cl. 8.

31. U.S. CONST. art. I, $\S 8$, cl. 3 .

32. Fla. Prepaid, 527 U.S. at 635-36.

33. See 517 U.S. 44, 65-73 (1996) (overruling Pennsylvania v. Union Gas Co., 491 U.S. 1 (1989), and holding that the Eleventh Amendment restricts judicial power under Article III and that Article I cannot be used to circumvent constitutional limits placed on federal jurisdiction).

34. See Fla. Prepaid, 527 U.S. at 636 ("Seminole Tribe makes clear that Congress may not abrogate state sovereign immunity pursuant to its Article I powers ...."). The Patent Remedy Act was passed before the decision in Seminole Tribe was handed down. Patent and Plant Variety Protection Remedy Clarification Act, Pub. L. No. 102-560, 106 Stat. 4230 (1992) (codified as amended at 35 U.S.C. $\S \S 271(\mathrm{~h}), 296($ a) (1994)). 
Even though the Court affirmed that Congress validly may abrogate state sovereign immunity under Section 5 of the Fourteenth Amendment and that patents are a cognizable form of property under the Fourteenth Amendment, it held that the Patent Remedy Act was not a valid exercise of this congressional power. ${ }^{35}$ It failed to satisfy the congruence and proportionality test established in City of Boerne v. Flores. ${ }^{36}$

According to the Court, the legislative record of the Patent Remedy Act did not demonstrate that Congress intended to remedy a specific Fourteenth Amendment violation. ${ }^{37}$ A constitutional violation occurs only when the state provides inadequate remedies when it infringes on patent owners' property rights without due process. ${ }^{38}$ The Act did not respond to a history of widespread deprivations of due process rights or target a specific constitutional wrong, as City of Boerne required. ${ }^{39}$ The Court also held that the Act's reach was disproportional to the wrong to be remedied because it was a blanket response instead of one tailored to the worst types of infringement or the worst state offenders. ${ }^{40}$

In College Savings Bank, ${ }^{41}$ the plaintiff bank filed a false advertising and unfair competition suit under the Lanham Act and alleged that the defendant state agency made misstatements about its tuition savings program in its brochures and annual reports. ${ }^{42}$ The Supreme Court granted a writ of certiorari after the Third Circuit affirmed the district court's dismissal of the bank's Lanham Act suit against the state agency. ${ }^{43}$ Both lower courts had rejected the bank's arguments that Florida Prepaid's immunity had been waived or abrogated. ${ }^{44}$

The Court considered whether one of the two recognized circumstances in which a state may be subjected to suit existed: had Congress abrogated the state's immunity under Section 5 of the Four-

\footnotetext{
35. Fla. Prepaid, 527 U.S. at $642,647$.

36. See id. at 645-46 (ruling that the Patent Remedy Act's provisions were too far out of proportion to a supposed remedial objective to have been designed to prevent unconstitutional behavior).

37. Id. at $643-44$.

38. Id. at 643 .

39. Id. at 645-46.

40. See id. at 646-47 (noting that Congress did nothing to limit the Act's broad coverage).

41. Coll. Sav. Bank v. Fla. Prepaid Postsecondary Educ. Expense Bd., 527 U.S. 666 (1999).

42. Id. at 671 .

43. Id. at 671-72.

44. Id. at 672 .
} 
teenth Amendment, or had the state waived immunity by consenting to suit $?^{45}$ The Court concluded that Congress did not successfully abrogate the state's immunity. ${ }^{46}$ It did not even reach the City of Boerne test here, because it held that the right to be free from a competitor's false advertising was not a property right under the Fourteenth Amendment, ${ }^{47}$ therefore, the government could not have deprived the bank of its property rights without due process.

Next, the Court concluded that Florida Prepaid did not expressly consent to this suit in federal court or voluntarily invoke federal court jurisdiction. ${ }^{48}$ College Savings Bank contended that Florida Prepaid impliedly or constructively waived its immunity per the doctrine set out in Parden v. Terminal Railway of Alabama State Docks Department. ${ }^{49}$ The Court rejected this reasoning and expressly overruled Parden, holding that a state's waiver of sovereign immunity must be express, unequivocal, and voluntary. ${ }^{50}$

\section{Possible Congressional Alternatives}

As mentioned above, the Florida Prepaid and College Savings Bank decisions have left victims of patent, trademark, and presumably copyright infringement with very limited remedies against the state. Section A discusses how the options presently available to these victims are wholly inadequate. Section B discusses the Spending Clause options, including the conditional waiver scheme that this Note proposes is the best solution available to Congress. Finally, Section $\mathrm{C}$ discusses other congressional alternatives and explains why they are less satisfactory than the conditional waiver plan.

45. See id. at 670 (recognizing these circumstances as the only two in which an individual can sue a state).

46. Id. at 675 .

47. Id.

48. Id. at 676 .

49. 377 U.S. 184, 191 (1964), discussed in Coll. Sav. Bank, 527 U.S. at 676. Parden stood for the proposition that a state constructively may waive its sovereign immunity by engaging in commerce among the states. See Parden, 377 U.S. at 191-92 (holding that FELA abrogated a state-owned railroad's sovereign immunity). The Parden Court reasoned that the states surrendered a portion of their sovereign immunity when they gave Congress the power to regulate interstate commerce and participated in that commerce. Id.

50. Coll. Sav. Bank, 527 U.S. at 680-81. 


\section{A. Current Mechanisms to Sidestep Florida Prepaid and College Savings Bank}

The only option left for victims of state intellectual property infringement is to sue state officials under the Ex Parte Young ${ }^{51}$ doctrine. This doctrine is the primary means to assert claims against the state; it permits individuals to initiate suits against state officers instead of against the state itself. ${ }^{52}$ Additionally, 42 U.S.C. $\S 1983$ permits suits against state officers in their personal capacities. ${ }^{53}$ If the officials were held liable for damages and completely indemnified, this system could operate in a similar fashion to direct governmental liability. ${ }^{54}$ However, such lawsuits would not adequately meet the needs of victims of intellectual property infringement, because victims of infringement are entitled only to prospective, injunctive relief against state officials. ${ }^{55}$ Therefore, if the infringement has already occurred and the monetary loss was significant, the victim would have no remedy for its injuries.

Another problem with the current system is that many state officials enjoy qualified immunity from suit. Ex Parte Young provides that a citizen may sue a state official for damages only for actions that are outside the scope of his duties. ${ }^{56}$ It also can be very difficult to determine which official is the proper defendant in the infringement suit. ${ }^{57}$ Professor Daniel J. Meltzer recently told the Senate Judiciary Committee that "juries may hesitate to award adequate damages against individual officers serving the public under often difficult conditions." ${ }^{58}$ A system that allows for only partial or no relief for intellectual property infringement is inadequate. ${ }^{59}$

\footnotetext{
51. 209 U.S. 123 (1908).

52. Thomas, supra note 13 , at 1100.

53. See Hafer v. Malo, 502 U.S. 21, 29-30 (1991) ("[T]he Eleventh Amendment does not erect a barrier against suits to impose 'individual and personal liability' on state officials under § 1983.”).

54. Hearings on State Sovereign Immunity, supra note 4, at 44 (statement of Daniel Meltzer).

55. See Edelman v. Jordan, 415 U.S. 651, 664-66 (1974) (placing limits on the injunctive relief available under the Ex Parte Young doctrine). ters).

56. Hearings on State Sovereign Immunity, supra note 4, at 23 (statement of Marybeth Pe-

57. See id. at 44 (statement of Daniel J. Meltzer) (noting the difficult burden of determining which state officials to hold personally liable).

58. Id.

59. Another inadequacy with an Ex Parte Young suit is the recently added restrictions pronounced in Seminole Tribe v. Florida, 517 U.S. 44 (1996). Federal courts may not now allow Ex
} 
Several commentators suggest that victims of intellectual property infringement may be able to bring an inverse condemnation proceeding, based in federal law, to receive compensation for the state's unlawfully taking their private property. ${ }^{60}$ Most states' constitutions' condemnation clauses provide for payment of just compensation when the government takes private property for public use. ${ }^{61}$ These commentators contend that victims of intellectual property infringement committed by a state should be able to claim that the state has committed a taking. ${ }^{62}$ A full discussion of this notion is beyond the scope of this Note; here I discuss only why this is not an adequate remedy.

First, the status of many types of intellectual property rights with respect to the takings statutes are unclear. ${ }^{63}$ "There is no case law on whether intellectual property interests would be governed by inverse condemnation statutes. ${ }^{\circ 6}$ Second, relying upon a takings cause of action offers the victim only minimal damages. Federal intellectual property law provides infringement victims with a number of remedies. The Lanham Act, ${ }^{65}$ the Copyright Act, ${ }^{66}$ and the Patent Act

Parte Young actions against a state when a complete, legislatively crafted remedy is already in existence, see Thomas, supra note 13 , at 1088 , and state officers cannot be sued to quiet title to submerged lands, see CHEMERINSKY, supra note 11, at 429.

60. See, e.g., Shubha Ghosh, Toward a Theory of Regulatory Takings for Intellectual Property: The Path Left Open After College Savings Bank v. Florida Prepaid, 37 SAN DIEGo L. Rev. 637,651 (2000) ("[T]he Takings Clause is the strongest available avenue for bringing a claim of infringement against a state government."); Paul J. Heald \& Michael L. Wells, Remedies for the Misappropriation of Intellectual Property by State and Municipal Governments Before and After Seminole Tribe: The Eleventh Amendment and Other Immunity Doctrines, 55 WASH. \& LEE L. REV. 849, 872 (1998) (stating that inverse condemnation proceedings have been initiated when the state has appropriated an individual's intellectual property); John O'Connor, Note, Taking TRIPS to the Eleventh Amendment: The Aftermath of the College Savings Cases, 51 HastingS L.J. 1003, 1017-29 (2000) (describing litigation strategies, including due process eminent domain claims).

61. 6A Julius L. SACKMAn, Nichols on Eminent Domain $§ 30.01[2]$, at 30-10 (3d ed. 2000); Cecily Anne Snyder, Comment, Can the United States Meet Its Obligation to Protect Intellectual Property Rights Under the International GATT/TRIPs Agreement After the Florida Prepaid Cases?, 35 U.S.F. L. REV. 407, 432 (2001).

62. See supra note 60 .

63. See infra notes $243-46$ and accompanying text (discussing what constitutes "property" under the Fourteenth Amendment); see also Heald \& Wells, supra note 60, at 855-73 (discussing the infringement of intellectual property rights as a Fifth Amendment taking).

64. Ghosh, supra note 60, at 663 .

65. Lanham Act, 15 U.S.C. $\S \S 1051-1129$ (1994 \& Supp. V 1999).

66. Copyright Act, 17 U.S.C. $\S \S 101-1332$ (1994 \& Supp. V 1999).

67. Patent Act, 35 U.S.C. $\S § 1-376$ (1994 \& Supp. V 1999). 
provide for injunctions. ${ }^{68}$ The Lanham Act also provides for consequential, statutory, and treble damages in trademark cases. ${ }^{69}$ The Copyright Act provides for consequential and statutory damages in copyright violation cases, ${ }^{70}$ and the Patent Act provides for treble damages for patent infringement. ${ }^{71}$ By contrast, under takings law, a plaintiff may not secure injunctive relief, ${ }^{72}$ consequential damages (i.e., loss of profits and goodwill), ${ }^{73}$ or treble damages. ${ }^{74}$ A third problem with relying on a takings claim is the forum; takings actions against state governments must be brought in state courts; whereas federal courts, which are often a more desirable forum for an injured plaintiff, are available under federal intellectual property law. ${ }^{75}$

In sum, neither the Ex Parte Young doctrine nor a inverse condemnation proceeding provides an intellectual property infringement victim with the robust remedies provided for in the intellectual property statutes. It therefore is necessary to consider whether a more promising option is available to Congress.

\section{B. Options Based on Congress's Spending Power}

The Supreme Court has recognized that Congress has broad power under the Spending Clause to impose conditions upon the dispensing of federal benefits or gratuities. ${ }^{76}$ The Spending Clause gives the federal government power "[t]o lay and collect Taxes, Duties,

68. 15 U.S.C. $\S 1116$ (a) (trademark and unfair competition cases); 17 U.S.C. $§ 502$ (copyright cases); 35 U.S.C. $\$ 283$ (patent cases).

69. 15 U.S.C. $\$ 1117$.

70. 17 U.S.C. $\$ 504$.

71. 35 U.S.C. $\$ 284$.

72. Heald \& Wells, supra note 60 , at 874 .

73. United States v. General Motors Corp., 323 U.S. 373, 379 (1945) (denying recovery for future loss of profits, loss of goodwill, and other similar consequential damages).

74. Heald \& Wells, supra note 60, at 874; O'Connor, supra note 60, at 1025.

75. Heald \& Wells, supra note 60 , at 875 .

76. See, e.g., South Dakota v. Dole, 483 U.S. 203, 206 (1987) (upholding the conditioning of federal highway funds on states adopting a legal drinking age of twenty-one); Fullilove v. Klutznick, 448 U.S. 448, 474 (1980) (upholding a federal program that conditioned receipt of public works grants upon agreement by the state or local governments that ten percent of the funds go to minority businesses); Oklahoma v. United States Civil Serv. Comm'n, 330 U.S. 127, 143-44 (1947) (holding that conditioning federal funds on state officers' not participating in political activities is a valid use of the spending power); see also Brett D. Proctor, Note, Using the Spending Power to Circumvent City of Boerne v. Flores: Why the Court Should Require Constitutional Consistency In Its Unconstitutional Conditions Analysis, 75 N.Y.U. L. REV. 469, 469 (2000) ("Congress's power to condition its discretionary allocations of funds is remarkably broad ...."). 
Imposts and Excises, to pay the Debts and provide for the common Defence and general Welfare of the United States." gives Congress the authority to legislate on an issue indirectly in a way that it could not legislate directly. ${ }^{78}$ The power Congress possesses under the Spending Clause is contractual in nature: "in return for federal funds, the States agree to comply with federally imposed conditions." 79 However, as with any contract, the parties have to accept the terms of the contract voluntarily and knowingly, and when Congress imposes conditions in exchange for federal gratuities, it must do so explicitly. ${ }^{80}$ States receiving the federal benefit must have notice of the conditions and the consequences if the conditions are not followed. ${ }^{81}$

Congress could consider two options based on the spending power to subject states to suit for their violations of individuals' intellectual property rights: condition the granting of federal intellectual property protection on states' waiving their sovereign immunity in federal court or condition the granting of federal funds on states' waiving their sovereign immunity. The best alternative available to Congress is to condition the receipt of federal protection for intellectual property rights owned by the state on states' waiving their immunity from such suits in federal court.

1. Condition State Participation in the Federal Intellectual Property System on States' Waiving Their Sovereign Immunity in Federal Court. Under the legislation advocated by this Note, a state will be able to acquire a federal intellectual property right only upon agreeing to waive its sovereign immunity from suit in federal court in an action against it arising under federal intellectual property law. ${ }^{82}$

77. U.S. CONST. art. I, § 8, cl. 1 .

78. See, e.g., Dole, 483 U.S. at 212 ("Even if Congress might lack the power to impose a national minimum drinking age directly, we conclude that encouragement to state action ... is a valid use of the spending power.").

79. Pennhurst State Sch. \& Hosp. v. Halderman, 451 U.S. 1, 17 (1981).

80. Davis v. Monroe County Bd. of Educ., 526 U.S. 629, 640 (1999); Pennhurst, 451 U.S. at 17 ("There can, of course, be no knowing acceptance if a State is unaware of the conditions or is unable to ascertain what is expected of it.").

81. Gebser v. Lago Vista Indep. Sch. Dist., 524 U.S. 274, 287 (1998).

82. This proposal was suggested by the Copyright Office during congressional hearings and has some support from most of the experts who testified. See Hearings of State Sovereign Immunity, supra note 4, at 27, 34, 55 (statements of Marybeth Peters, Daniel J. Meltzer, and Mark A. Lemley). Senator Leahy also introduced it as part of a bill during the 106th Congress. S. 1835, 106th Cong. (1999). 
Authority for such legislation derives from conditional spending cases. The federal government would be in effect conditioning a gratuity-the receipt of federal protection for state intellectual property-on states' voluntarily waiving their sovereign immunity in federal court. ${ }^{83}$ Professor Meltzer skillfully explained the argument supporting this proposal:

(a) Congress need not create intellectual property rights; (b) thus, from the states' standpoint, the property rights they enjoy under federal IP [Intellectual Property] schemes are gratuities; (c) in dispensing those gratuities, Congress may condition them on a state's waiving immunity; (d) and, therefore, Congress may provide that a state cannot obtain new IP rights unless it agrees to waive immunity from suit under federal IP schemes. ${ }^{84}$

Congress is under no obligation to create intellectual property laws. The wording of the Patent Clause is not obligatory: "The Congress shall have Power ... To promote the Progress of Science and useful Arts, by securing for limited Times to Authors and Inventors the exclusive Right to their respective Writings and Discoveries." 85 The Constitution gives Congress the power to create these intellectual property rights but includes no mandate that it do so. ${ }^{86}$

83. States obtain intellectual property rights for a plethora of inventions, writings, etc. For example, all inventions from state universities may be patented. zer).

84. Hearings on State Sovereign Immunity, supra note 4, at 50 (statement of Daniel J. Melt-

85. U.S. CONST. art. I, $\S 8$, cl. 1,8 .

86. One district court expressly has agreed that the Intellectual Property Clause of the Constitution does not create an entitlement after the Florida Prepaid decisions were handed down. The District Court for the Eastern District of California held that the Regents of the University of California waived their Eleventh Amendment immunity by acquiring a patent under the Patent Act. New Star Lasers, Inc. v. Regents of the Univ. of Cal., 63 F. Supp. 2d 1240, 1244-45 (E.D. Cal. 1999) (citing Coll. Sav. Bank v. Fla. Prepaid Postsecondary Educ. Expense Bd., 527 U.S. 666, 686-87 (1999)). The court noted that the Supreme Court in College Savings Bank "re-affirmed Petty v. Tennessee-Missouri Bridge Commission and South Dakota v. Dole, which held that Congress may require a waiver of State sovereign power as a condition on the approval of an interstate compact or on the receipt of federal funds." Id. at 1243 (citations omitted). In New Star Lasers, the plaintiff sued the state to have one of the state's patents declared invalid. Id. at 1241. The court rejected the state's request that the court dismiss the claim on the grounds of sovereign immunity. Id. at 1242. It reasoned that "a patent constitutes a 'gift or gratuity' bestowed by the federal government, and if Congress has conditioned its receipt on a waiver of Eleventh Amendment immunity to a declaratory suit, then Congress has acted permissibly." Id. at 1244 (citations omitted). 
Since the 1930s, the Supreme Court consistently has upheld federal conditioning schemes. "No federal appropriations program has been invalidated by the Supreme Court on federalism-based grounds since 1936." ${ }^{88}$ The Court has been very frank that this power gives the federal government the ability to carry out its objectives constitutionally even when it would not be able to do so directly. ${ }^{89}$ Many of the most important government programs today are conditional spending programs, including Titles VI and IX of the Civil Rights of $1972^{90}$ and the Medicaid statute. ${ }^{91}$ Other examples of conditional spending legislation include the Individuals with Disabilities Education Act, ${ }^{92}$ Title $\mathrm{X}$ of the Public Health Service Act, ${ }^{93}$ and the Food Security Act. ${ }^{94}$ Congress validly has attached many different kinds of conditions to federal highway funds, including raising the drinking age to twentyone ${ }^{95}$ adhering to a national speed limit of fifty-five miles per hour, ${ }^{96}$

87. See supra note 76 and accompanying text; infra notes $110-11,161-66,174$ and accompanying text.

88. Proctor, supra note 76, at 469.

89. See, e.g., South Dakota v. Dole, 483 U.S. 203, 212 (1987) ("Even if Congress might lack the power to impose a national minimum drinking age directly, we conclude that encouragement to state action . . . is a valid use of the spending power."); United States v. Butler, 297 U.S. 1, 66 (1936) ("[T] purposes is not limited by the direct grants of legislative power found in the Constitution.").

90. See Davis v. Monroe County Bd. of Educ., 526 U.S. 629, 640 (1999) ("[W]e have repeatedly treated Title IX as legislation enacted pursuant to Congress' authority under the Spending Clause ....”); Gebser v. Lago Vista Indep. Sch. Dist., 524 U.S. 274, 286 (1998) ("The two statutes operate in the same manner, conditioning an offer of federal funding on a promise by the recipient not to discriminate, in what amounts essentially to a contract between the Government and the recipient of funds."); Robinson v. Kansas, 117 F. Supp. 2d 1124, 1133 (D. Kan. 2000) (holding that Kansas validly waived its immunity by accepting federal funds under Title VI, because federal funds are a "gift or gratuity" from the federal government).

91. Makin v. Hawaii, 114 F. Supp. 2d 1017, 1027 (1999) (noting that Medicaid is a valid use of the conditional spending power).

92. 20 U.S.C. $\S \S 1401(a)(18), 1412(1)$ (1994) (authorizing federal funds for states on the condition they provide disabled children with special education and "related services"); see also Cedar Rapids County Sch. Dist. v. Garret F., 526 U.S. 66, 68 (1999) (upholding the Individuals with Disabilities Education Act's condition requiring the provision of "related services").

93. See Rust v. Sullivan, 500 U.S. 173, 195 n.4 (1991) (upholding Title X as a conditional spending measure and holding that funds to states may be conditioned on their not being used to promote or advocate abortion as a method of family planning).

94. See United States v. Dierckman, 201 F.3d 915, 922 (7th Cir. 2000) (holding that the Food Security Act validly conditions receipt of United States Department of Agriculture farm benefits on the preservation of wetlands).

95. South Dakota v. Dole, 483 U.S. 203, 212 (1987).

96. Nevada v. Skinner, 884 F.2d 445, 446 (9th Cir. 1989) 
and prohibiting some state employees from participating in political management or political campaigns. ${ }^{97}$

In the leading case, South Dakota v. Dole, ${ }^{98}$ the Court held that Congress has the power to condition the receipt of a percentage of federal highway funds on each state's raising its drinking age to twenty-one. ${ }^{99}$ In this case, the Court laid out a four-part test to determine whether Congress had properly enacted legislation under the Spending Clause: (1) the legislation must have been in pursuit of the general welfare; (2) the condition must have been unambiguous; (3) the conditions must have been related to the federal interest involved; and (4) no other constitutional provisions may have provided "an independent bar to the conditional grant of federal funds." 100

The first part of the test, whether the legislation was enacted in pursuit of the general welfare, is not a meaningful restriction, because Congress shapes the concept of welfare. ${ }^{101}$ The courts are required to defer substantially to Congress with regard to this requirement. ${ }^{102}$ No court has struck down spending power legislation based on this factor. ${ }^{103}$ The second part of the test is satisfied as long as the statute's provisions are very explicit. ${ }^{104}$ The state has to know exactly what it will be giving up by accepting the gratuity.

A court need apply only a general rational basis test to satisfy the third requirement. In analyzing this factor, the court will inquire whether Congress could have rationally believed that the condition is related to the federal interest involved. ${ }^{105}$ In analyzing the fourth fac-

97. Oklahoma v. United States Civil Serv. Comm'n, 330 U.S. 127, 129 (1947) (noting that the particular employee in this case was a member of the State Highway Commission).

Brett Proctor, in a note written about the Spending Clause, lists several more examples of how the spending power could be used to circumvent the Supreme Court's recent federalism mandates. Some of these possibilities would seek to reenact provisions of the Gun-Free School Zones Act of 1990, which was struck down in United States v. Lopez, 514 U.S. 549 (1995), and the Brady Act, struck down by Printz v. United States, 521 U.S. 898 (1997). Proctor, supra note 76 , at 470 .

98. 483 U.S. 203 (1987).

99. Id. at 212 .

100. Id. at 208.

101. Id.

102. Id. at 207.

103. Albert J. Rosenthal, Conditional Federal Spending and the Constitution, 39 STAN. L. REV. 1103, 1113 (1987).

104. See Dole, 483 U.S. at 208 (holding that the conditions upon which the states "receive the funds ... could not be more clearly stated by Congress").

105. See id. (noting that "the condition imposed by Congress is directly related to one of the main purposes for which highway funds are expended-safe interstate travel"). 
tor, the Supreme Court has emphasized that the independent constitutional bar factor is not a proscription against indirectly accomplishing what Congress could not do directly. ${ }^{106}$ This factor simply indicates that Congress may not condition funds on states' performing unconstitutional activities, such as discriminating or inflicting cruel or unusual punishment. ${ }^{107}$

Though it is not technically a component of the four-prong test, the Dole Court imposed a further restriction on Congress's power under the Spending Clause: the condition may not be "so coercive as to pass the point at which "pressure turns into compulsion." "108 The Court has not prescribed any bright-line formula with which to evaluate this factor; it is usually decided on a case-by-case basis. ${ }^{109}$ The Supreme Court has held a federal conditional spending measure to be coercive only once, in United States v. Butler, ${ }^{110}$ in $1936 .{ }^{111}$ However, the Court "effectively demolished some of the premises of the Butler case" ${ }^{112}$ in a case decided only one year later, Steward Machine Co. v. Davis, ${ }^{113}$ and never struck down a conditional spending measure on coercion grounds again.

The conditional waiver scheme should pass this undemanding test. This legislation would be in pursuit of the general welfare, unambiguous, related to the federal interest involved, and no other constitutional provisions would impose an independent bar. The scheme also would also pass the coercion test acknowledged in Dole.

Congress established that making all parties, including the states, amenable to federal intellectual property laws is in the general welfare by passing several different statutes designed to accomplish that

\footnotetext{
106. Id. at 210.

107. Id.

108. Id. at 211 (quoting Steward Mach. Co. v. Davis, 301 U.S. 548, 590 (1937)).

109. See Rosenthal, supra note 103, at 1121 ("Where the validity of coercive conditions on spending has been under consideration, the growing tendency of the Supreme Court has been to weigh them case by case rather than to try to resolve them by reference to some broad formulation relating to unconstitutional conditions.").

110. 297 U.S. 1 (1936). Incidentally, this case was also the first time the Supreme Court considered the Spending Clause issue extensively.

111. Rosenthal, supra note 103, at 1127. In Butler, the Court held that Congress could not condition payments to farmers on their agreeing to curtail acreage or production. 297 U.S. at $74-75$.

112. Rosenthal, supra note 103 , at 1127.

113. 301 U.S. 548, 583 (1937) (holding that the Social Security Act of 1935, which conditions a federal gratuity on states' enacting unemployment compensation laws, is constitutional).
} 
goal ${ }^{114}$ therefore, the first prong of the test should be satisfied easily by this scheme. The second prong of the Dole test also should not be difficult to satisfy as long as the bill Congress adopts explicitly details the terms and consequences of the conditional gratuity measure.

The third prong, requiring that the condition be related to the federal interest involved, is easily satisfied because the condition and the gratuity are closely related here. As the Register of Copyrights notes, "[t]here is a symmetry to this approach.","15

In fact, the relatedness requirement is one advantage this proposal would have over a normal conditional spending scheme involving federal funds. It is difficult to imagine what kinds of funds Congress could agree to disburse on the condition that states waive their immunity in intellectual property infringement actions. ${ }^{116}$ The link between federal intellectual property rights and states' waiving their immunity in such actions seems at least as close as the drinking agesafe highway travel link approved in Dole. The goals of conditioning the receipt of federal protection for states' intellectual property rights on states' waiving their immunity and the goals of the federal intellectual property system itself are identical - to provide for a uniform, fair system to protect and promote useful works and inventions.

A recent article suggests that a waiver provision of this sort would have difficulties passing constitutional muster with the Supreme Court because of the "unconstitutional conditions" doctrine. ${ }^{117}$ Under this doctrine, a condition imposed by the government must be germane and not coercive. ${ }^{118}$ After concluding that the conditional waiver scheme is not coercive, the article's author argues that the waiver provisions are not germane or related closely enough to the

114. See 35 U.S.C. § 296 (1994) (patents); 15 U.S.C. § 1122 (1994) (trademarks); 17 U.S.C. $\S 511$ (1994) (copyrights).

115. Hearings on State Sovereign Immunity, supra note 4, at 27 (statement of Marybeth Peters).

116. See infra notes $184-85$ and accompanying text.

117. See Cross, supra note 7, at 375 (arguing that conditional waivers are unconstitutional when the conditions imposed "go too far"). The "unconstitutional conditions" doctrine "holds that government may not grant a benefit on the condition that the beneficiary surrender a constitutional right, even if the government may withhold that benefit altogether." Kathleen M. Sullivan, Unconstitutional Conditions, 102 HARV. L. REV. 1415, 1415 (1989). The courts have held the term "unconstitutional conditions" to encompass "personal liberties of speech, association, religion, and privacy." Id. at 1416. "[C]urrent constitutional law treats most governmental benefits as 'gratuities': matters of political grace to be deferentially reviewed." Id. at 1424.

118. Cross, supra note 7, at 377-78. 
gratuity. ${ }^{119}$ The article applies a stricter test than the relatedness prong test applied in Dole: "[a] connection with the overall legislative program will not suffice. Instead, the Court looks for a connection between the condition and the purposes of the government benefit to which that condition is attached."

Citing Supreme Court precedents from Takings Clause jurisprudence $^{121}$ and a Fourth Circuit case, ${ }^{122}$ the article concludes that "whether a State can be liable for copying the work of another has little to do with whether it should receive a legal monopoly for other works that it prepares independently." ${ }^{123}$ However, the conditional waiver scheme much more closely parallels Supreme Court Spending Clause jurisprudence than Takings Clause jurisprudence. The Court, in its Spending Clause cases, has consistently applied only a rational basis standard in judging legislation under the germanenessrelatedness requirement. The conditional waiver scheme proposed here more than adequately satisfies the rational basis standard and has a tighter connection than the article contends. As recently as 1992, the Supreme Court has described this prong of the test as being satisfied when the condition "bear[s] some relationship to the purpose of the federal spending." 124 The District of Columbia Circuit re-

119. Id. at 378-86. In concluding that the conditions were not overly coercive, the article reasons that:

[A] condition is coercive only when the benefit to which it is attached is extremely important to the recipient. Ownership of federal intellectual property rights is not that crucial to a State. Although ... intellectual property rights are undoubtedly a valuable revenue source, a State can always turn to taxes and other funding options. Moreover, in some cases the State may be able to preserve part of the revenue attributable to an invention or artistic or literary work in other ways, such as state contract, trademark, or trade secret laws.

Id. at 378 .

120. Id. at 382 . The article dismisses several passages from previous opinions that have only applied a germaneness test to the overall project. See id. at $382 \&$ n.10. Note also that the Supreme Court specifically approved these decisions in Dole. South Dakota v. Dole, 483 U.S. 203, 208 (1987).

121. Dolan v. City of Tigard, 512 U.S. 374, 386 (1994) (holding that courts must evaluate the "essential nexus" between "state interest" and a land-use condition); Nollan v. Cal. Coastal Comm'n, 483 U.S. 825, 834 (1987) (holding that land-use regulation is not a taking if it advances state interests and does not completely deny the owner use of the land). Both of these cases dealt with the Takings Clause as applied to the states via the Fourteenth Amendment, specifically with conditions states placed on building permits.

122. See Litman v. George Mason Univ., 186 F.3d 544, 554 (4th Cir. 1999) (holding that a public university had waived its immunity by accepting Title IX funding and thus agreeing to the clear condition of waiver Congress attached to the funds).

123. Cross, supra note 7, at 386 .

124. New York v. United States, 505 U.S. 144, 167 (1992). 
jected a stricter test as completely contrary to case law. ${ }^{125}$ And the Supreme Court has given no indication that this prong will be examined more strictly in the future..$^{126}$

The last prong of the Dole test requires that there not be any independent constitutional bar to the conditions. As with the other Dole factors, this requirement should not be difficult to satisfy. The Spending Clause power may not be used to coerce states into engaging in unconstitutional pursuits, like cruel or unusual punishment or discrimination in violation of the Equal Protection Clause. Clearly, states' waiving their own immunity is not unconstitutional; therefore, this prong of the Dole test should not present an obstacle to the conditional waiver scheme.

The Court also may require this conditional waiver plan to pass the coercion test. Theoretically, if a condition passes the point where pressure turns into compulsion, then it may be struck down. ${ }^{127}$ Another recent article suggests that a conditional waiver plan of this sort should fail under this prong. ${ }^{128}$ The article expresses doubt as to whether the coercion test applied in Dole is a good one, because its results are "too arbitrary." 129 The authors reason that, in analyzing whether the condition was coercive, the Dole Court focused "on the percentage of federal benefit at stake," and the conditional waiver scheme would "withhold federal intellectual property protection from one hundred percent of a state's future innovations." "130 Although they admit it is very difficult to determine how much is " "too much' pres-

125. See Oklahoma v. Schweiker, 655 F.2d 401, $406-07$ (D.C. Cir. 1981) (rejecting the notion that a condition must be precisely related to the purpose of the federal funds that are granted subject to the condition).

126. Justice O'Connor indicated in her dissent in Dole that she would require a tighter fit under this prong, but her opinion has never been accepted by a majority of the Court. See South Dakota v. Dole, 483 U.S. 203, 215-16 (1997) (O'Connor, J., dissenting) (noting that the difference turns on whether the condition specifies how the money should be spent).

127. John O'Connor, in a note, argues that a conditional gratuity scheme like that in Senator Leahy's Senate Bill 1835 will not pass the coercion test. See O'Connor, supra note 60, at 1043-44 (arguing that the bill will not pass the test due to its punitive measures and its attempt to redefine constitutional rights). However, his cursory examination fails to weigh properly all the facts and pertinent law. See infra note 188 and accompanying text.

128. See Berman et al., supra note 7, at 1151-55 (claiming that the bill probably fails due to the high percentage of "federal benefits at stake"). Note that although the authors maintain that this type of bill would not pass constitutional muster, they concede that "it is conceivable that a majority of the present Court would uphold the bill even while purporting to apply Dole." Id. at 1147.

129. Id. at 1154 .

130. Id. at 1152 . 
sure on states," the authors seem to believe that withholding federal protection for state intellectual property is "too much.",131

In practice, however, the coercion test has not been a meaningful obstacle. Several other conditional spending measures with even more severe conditions have passed constitutional muster. The Eighth Circuit held that, "[t]he sacrifice of all federal education funds, approximately $\$ 250$ million or 12 per cent. of the annual state education budget ... would be politically painful, but we cannot say that it compels Arkansas's choice." ${ }^{, 132}$ The antidiscrimination statutes require the state to waive its sovereign immunity if the state receives federal funds for any of the listed programs or activities. ${ }^{133}$ Title VI consistently has been upheld as proper legislation under the Spending Clause and has never even been challenged for being coercive, even though it "condition[s] every dollar given to the states on compliance with federal demands." 134 The Ninth Circuit upheld against a coercion challenge the federal government's conditioning of California's receipt of Medicaid funds on the state's providing emergency medical services to illegal aliens. ${ }^{135}$

Significant evidence suggests that the coercion test has limited substance and applicability. As far back as 1937, Justice Cardozo, writing for the Supreme Court, expressed doubts about the relevance of this test:

[T]o hold that motive or temptation is equivalent to coercion is to plunge the law in endless difficulties. The outcome of such a doctrine is the acceptance of a philosophical determinism by which choice becomes impossible .... Nothing in the case suggests the exertion of a power akin to undue influence, if we assume that such a concept can ever be applied with fitness to the relations between state and nation. ${ }^{136}$

Several appellate court decisions have exhibited similar skepticism about the applicability of the coercion doctrine. For example, in Nevada v. Skinner, ${ }^{137}$ the Ninth Circuit expressed doubts over the

\footnotetext{
131. Id. at 1155 .

132. Jim C. v. United States, 235 F.3d 1079, 1082 (8th Cir. 2000) (en banc) (holding that the Rehabilitation Act of 1973 is a valid exercise of Congress's spending power) (emphasis added).

133. Lane v. Pena, 518 U.S. 187, 198 (1996); Jim C., 235 F.3d at 1081.

134. Proctor, supra note 76, at 490-91, 501.

135. California v. United States, 104 F.3d 1086, 1092 (9th Cir. 1997).

136. Steward Mach. Co. v. Davis, 301 U.S. 548, 589-90 (1937).

137. 884 F.2d 445 (9th Cir. 1989).
} 
meaning and relevance of the coercion test and seemed perplexed about what standards it should apply to discern whether the condition constituted coercion. ${ }^{138}$ It stated:

[C]an a sovereign state which is always free to increase its tax revenues ever be coerced by the withholding of federal funds-or is the state merely presented with hard political choices? The difficulty if not the impropriety of making judicial judgments regarding a state's financial capabilities renders the coercion theory highly suspect as a method for resolving disputes between federal and state governments. ${ }^{139}$

Eight years later, the Ninth Circuit affirmed this dictum from Skinner and again questioned the viability of the coercion requirement. ${ }^{140}$ The Tenth Circuit and the District of Columbia Circuit have exhibited similar skepticism over the coercion theory. ${ }^{141}$ One commentator concludes, "The doctrine of coercion justifiably has no significant applicability in unconstitutional conditions analysis today."

However, another author comments that language in College Savings Bank suggests the Supreme Court may put new bite into the coercion requirement with regard to state sovereign immunity. ${ }^{143} \mathrm{Near}$ the end of the majority opinion, Justice Scalia noted that "where the constitutionally guaranteed protection of the States' sovereign immunity is involved, the point of coercion is automatically passed-and the voluntariness of waiver destroyed-when what is attached to the refusal to waive is the exclusion of the State from otherwise lawful activity." 144

However, the language in this section is ambiguous and must be read in the context of the language around it. Here, the majority was discussing constructive waivers, not the kind of waiver scheme pro-

\footnotetext{
138. Id. at 448 .

139. Id. (footnotes omitted).

140. See California v. United States, 104 F.3d at 1092 (questioning whether there is any viability to the coercion challenge).

141. Kansas v. United States, 214 F.3d 1196, 1202 (10th Cir. 2000) ("[T]he coercion theory is unclear, suspect and has little precedent to support its application.”); Oklahoma v. Schweiker, 655 F.2d 401, 414 (D.C. Cir. 1981) ("The courts are not suited to evaluating whether the states are faced here with an offer they cannot refuse or merely a hard choice.").

142. Proctor, supra note 76, at 488-89.

143. See O'Connor, supra note 60, at 1031.

144. Coll. Sav. Bank v. Fla. Prepaid Postsecondary Educ. Expense Bd., 527 U.S. 666, 687 (1999).
} 
posed by this Note. ${ }^{145}$ Justice Scalia was concluding that constructive waivers of sovereign immunity are involuntary. In her testimony before Congress, the Register of Copyrights agreed with this conclusion: "the better reading of the relevant language is that implied waiver is inherently involuntary but that where Congress clearly gives the State a choice, so long as the choice is not coercive, a State's choice to explicitly waive its immunity is effective." 146 The Tenth Circuit also has interpreted Scalia's passage as applying only to constructive waivers. $^{147}$

An author writing after the Florida Prepaid decisions interprets College Savings Bank as allowing the federal government to "condition the grant of a patent or trademark to a state agency upon a waiver of sovereign immunity." served that the "coercion theory" discussed in College Savings Bank is merely dicta and not controlling. ${ }^{149}$ The Fifth Circuit added:

The Supreme Court has recognized that the tenth amendment permits Congress to attach conditions to the receipt by the states of federal funds that have the effect of influencing state legislative choices. "[T]o hold that motive or temptation is equivalent to coercion is to plunge the law in endless difficulties." This we will not do. ${ }^{150}$

In several cases since the Florida Prepaid and College Savings Bank decisions were handed down, appellate courts expressly have held that Congress may condition gratuities on states' waiving their immunity. In Litman v. George Mason University, ${ }^{151}$ the conservative Fourth Circuit held that a public university waived its immunity by

145. Constructive waivers are inexplicit waivers of sovereign immunity. A constructive waiver occurs, for example, when it is assumed that a state has waived its immunity by accepting federal funds, or initiating a suit in federal court.

146. Hearings on State Sovereign Immunity, supra note 4, at 27 (statement of Marybeth Peters).

147. See MCI Telecomm. Corp. v. Pub. Serv. Comm'n, 216 F.3d 929, 937 (10th Cir. 2000) (holding that a constructive waiver is voluntary only where a gift is denied, not when a sanction is imposed).

148. Ghosh, supra note 60 , at 657.

149. MCI Telecomm. Corp., 216 F.3d at 938-39 n.6.

150. Texas v. United States, 106 F.3d 661, 666 (5th Cir. 1997) (quoting South Dakota v. Dole, 483 U.S. 203, 211 (1987)) (footnotes omitted). A state unquestionably may waive its sovereign immunity by accepting federal funds. Atascadero State Hosp. v. Scanlon, 473 U.S. 234, 238 n.1 (1985); Sandoval v. Hagan, 197 F.3d 484, 493 (11th Cir. 1999); Clark v. California, 123 F.3d 1267, 1271 (9th Cir. 1997).

151. 186 F.3d 544 (4th Cir. 1999). 
accepting Title IX funding, and thus agreed to the clear condition of waiver Congress attached to the funds. ${ }^{152}$ The Fifth Circuit came to the same conclusion in Pederson v. Louisiana State University, ${ }^{153}$ and the Eleventh Circuit reached the same conclusion in Sandoval v. Hagan. $^{154}$

A Seventh Circuit case, MCI Telecommunications Corp. v. Illinois Bell Telephone Co., ${ }^{155}$ decided after Florida Prepaid and College Savings Bank, effectively illustrates how Congress may condition a gratuity on states' waiving their sovereign immunity. The court held that Congress's condition that states waive their sovereign immunity for the benefit of administering regulatory schemes that the federal government controlled previously was proper under the Eleventh Amendment. ${ }^{156}$ The court analogized this scheme to South Dakota v. Dole:

The state commissions have entered into the same kind of exchange with Congress that takes place when Congress offers federal funds conditioned on a state's acceptance of the federal terms. The only difference between the classic example of a Spending Clause gratuity of federal funds and the waivers in our cases is that, with the 1996 Telecommunications Act, Congress has offered the states, not federal funds, but a role as what the carriers have called a "deputized" federal regulator. In exchange for this grant of regulatory power, Congress has required the states to agree to submit to federal jurisdiction to review their actions. In Dole, the gratuity was money; the

152. Id. at 556-57. In Litman, the court reasoned that "a state may waive its Eleventh Amendment immunity by consenting to be sued in federal court" and that "[p]ermitting such waivers reflects the fact that sovereign immunity is an element of state sovereignty, not a categorical limitation on the federal judicial power." Id. at 550. The court went on to say that Spending Clause legislation "presents a state with a choice: the state can either comply with certain congressionally mandated conditions in exchange for federal funds or not comply and decline the funds." Id. at 552. Because the condition was unambiguous, and the state voluntarily and knowingly accepted it, the conditional scheme is valid. Id. at 554-55. The Court also addressed the affect of the Florida Prepaid cases in its conclusion:

[W]e do not read Seminole Tribe and its progeny, including the Supreme Court's recent Eleventh Amendment decisions, to preclude Congress from conditioning federal grants on a state's consent to be sued in federal court to enforce the substantive conditions of the federal spending program. Indeed, to do so would affront the Court's acknowledgement in Seminole Tribe of "the unremarkable ... proposition that States may waive their sovereign immunity."

Id. at 556 (quoting Seminole Tribe v. Florida, 517 U.S. 44, 65 (1996)).

153. 213 F.3d 858, 875-76 (5th Cir. 2000).

154. 197 F.3d 484, 492-94 (11th Cir. 1999).

155. 222 F.3d 323 (7th Cir. 2000).

156. Id. at 343-44. 
condition was a higher drinking age. Here, the gratuity is federal regulatory power; the condition is waiver of the state's immunity. ${ }^{157}$

The Telecommunications Act of 1996 also can be analogized to the conditional waiver scheme. Federal intellectual property rights, like the regulation of local phone service, are federal gratuities. Another analogy can be made to federal bankruptcy claims. The Tenth Circuit recently held that states must waive their sovereign immunity in bankruptcy claims as a condition to participation in the federal Perkins student loan programs. ${ }^{158}$

One could argue that because of the Supreme Court's recent invigoration of federalism limits on congressional power, the Dole test will be revised in the near future to establish a much stricter test. Although it is certainly true that certain areas of expansive federal regulation, most noticeably in the area of the Commerce Clause, have been drastically curtailed in the last decade, ${ }^{159}$ there is no reason to believe that the Supreme Court will change its Spending Clause jurisprudence anytime in the near future. ${ }^{160}$

The court consistently and recently has upheld spending power legislation against states' rights challenges. Less than ten years ago, in New York v. United States, ${ }^{161}$ the Court held that Congress could achieve indirectly through the Spending Clause some actions against a state that it could not constitutionally pursue directly. ${ }^{162}$ This case

157. Id. (footnote omitted); accord MCI Telecomm. Corp. v. Pub. Serv. Comm'n, 216 F.3d 929, 937-39 (10th Cir. 2000) (holding that the Telecommunications Act of 1996 "transformed the regulation of local phone service from an otherwise permissible state activity into a federal gratuity," and that the state validly waived its immunity by arbitrating a dispute for a local phone service) (footnotes omitted); AT\&T Communications, Inc. v. Southwestern Bell Tel. Co., 86 F. Supp. 2d 932, 947 (W.D. Mo. 1999) (holding that the Telecommunications Act does impose obligations on the state if the state chooses to be the arbiter of disputes).

158. In re Innes, 184 F.3d 1275, 1284 (10th Cir. 1999), cert. denied, 529 U.S. 1037 (2000); Federal Perkins Loan Program, 34 C.F.R. $\$ 674$ (2000).

159. See supra note 7 and accompanying text (analyzing the expansion of state governments' power at the expense of the federal government).

160. In an article written for a recent Spending Clause symposium in the Chapman Law Review, an author supporting a much weaker Spending Clause power for the federal government admits this proposition is true. "Thus far, the Supreme Court has not given any signal to suggest that it would apply its federalism rulings in the Spending Clause context, and the last major precedent on the subject strongly suggests that it would not." John C. Eastman, Restoring the "General" to the General Welfare Clause, 4 CHAP. L. REv. 63, 64 (2001) (citing South Dakota v. Dole, 483 U.S. 203 (1987)).

161. 505 U.S. 144 (1992).

162. Id. at 167 (holding that under Congress's spending power, Congress can attach conditions to receiving funds). 
arose as a challenge by a state to provisions in the federal Low-Level Radioactive Waste Policy Act. ${ }^{163}$ While explicitly upholding the conditional spending portion of the Act, the Court struck down other portions of the Act that required states to accept ownership of waste, or else regulate according to congressional instructions, as a violation of state sovereignty. ${ }^{164}$ Justice O'Connor, in her majority opinion, reasoned that the spending power is altogether different from the commerce power in its effect upon the sovereignty of the states. ${ }^{165}$ The Court also has recently affirmed the Dole test in Alden v. Maine ${ }^{166}$ and Metropolitan Washington Airports Authority $v$. Citizens for the Abatement of Aircraft Noise. ${ }^{167}$

The conditional spending and gratuity cases can be distinguished from other cases in which the Court has struck down federal schemes on federalism grounds, such as United States v. Lopez ${ }^{168}$ or United States v. Morrison. ${ }^{169}$ "In [those cases], the contention was that Congress had taken some action that was not within the scope of its enumerated powers. In Dole, by contrast, no one questioned the authority of Congress to spend funds for highway construction." ${ }^{170}$ Similarly, the federal government has discretion to use its powers to protect the intellectual property rights of its citizens and states. ${ }^{171}$

Some of these federalism decisions have used the Tenth Amendment to restrict the powers of the federal government. ${ }^{172}$ However, the Dole Court held that the Tenth Amendment is not an independent constitutional bar to conditional spending measures. It pointed out that "a perceived Tenth Amendment limitation on con-

\footnotetext{
163. Id. at 149 .

164. Id. at 173,177 .

165. Id. at 167 (noting that Congress has power to encourage a state to regulate in a particular way through either the conditional spending power or under the Commerce Clause by offering a state the choice of regulating in accordance with federal standards or having the laws preempted).

166. 527 U.S. 706, 755 (1999) ("Nor, subject to constitutional limitations, does the Federal Government lack the authority or means to seek the States' voluntary consent to private suits.").

167. 501 U.S. 252, 270-71 (1991).

168. 514 U.S. 549 (1995).

169. 529 U.S. 598 (2000).

170. Earl M. Maltz, Sovereignty, Autonomy and Conditional Spending, 4 CHAP. L. REV. 107, 113 (2001).

171. U.S. CONST., art. I, § 8, cl. 8 .

172. See Printz v. United States, 521 U.S. 898, 935 (1997) (holding that Congress may not conscript state officers directly to enforce regulation); New York v. United States, 505 U.S. 144, 168 (1992) (holding that Congress cannot compel states to enforce a regulatory program).
} 
gressional regulation of state affairs did not concomitantly limit the range of conditions legitimately placed on federal grants." ${ }^{173}$ The Supreme Court repeatedly has rebuffed challenges to the federal government's power under the Spending Clause as a violation of state immunity and sovereignty. ${ }^{174}$

Furthermore, although Justice O'Connor expressed some consternation over the laxity of the relatedness requirement of the Dole test ${ }^{175}$ a majority of the Court today would likely consider this test good law. Justice Rehnquist wrote the majority opinion in Dole and was joined by Justices Stevens and Scalia. ${ }^{176}$ It also seems very likely that the more liberal members of the Court, Justices Souter, Ginsburg, and Breyer, would be especially likely to uphold a conditional waiver scheme, judging from the consternation expressed in their dissent in the Florida Prepaid and College Savings Bank decisions. Justices Kennedy, Rehnquist, O'Connor, Scalia, and Thomas all have affirmed the Dole test recently. ${ }^{177}$ Although of course one could not

173. South Dakota v. Dole, 483 U.S. 203, 210 (1987).

174. For instance, in Oklahoma v. United States Civil Service Commission, 330 U.S. 127 (1947), the Court rejected a claim by the state that the penalty provisions of its conditional grant agreement with the federal government were unconstitutional under the Tenth Amendment. Id. at 143 (holding that as a condition of a grant of federal funds for highway construction, the state officers managing these funds may be required to desist from participating in some forms of partisan politics). Providing for the termination of a state officer for noncompliance with a federal grant agreement does not infringe on state sovereign immunity. Id. The Supreme Court also has held that conditioning federal funding on the achievement of milestones under the Low-Level Radioactive Waste Act was not inconsistent with the Tenth Amendment. New York v. United States, 505 U.S. at 173. The Ninth Circuit rejected a similar Tenth Amendment challenge in California v. United States, 104 F.3d 1986 (9th Cir. 1997), upholding a federal scheme that conditioned the receipt of Medicaid funds on the state's providing emergency medical care to illegal aliens. Id. at 1092-93.

175. Justice O'Connor's dissent in Dole centered on her disagreement with the Court's application of the third prong of the test, the relatedness requirement. Although the Court applied only a reasonableness standard, Justice O'Connor would require a tighter fit. She wrote that "[t]he difference turns on whether the requirement specifies in some way how the money should be spent... Congress has no power under the Spending Clause to impose requirements on a grant that go beyond specifying how the money should be spent." Dole, 483 U.S. at 216 (O'Connor, J., dissenting). This interpretation of the relatedness requirement has never been accepted by a majority of the Court.

176. These Justices rarely agree on federalism questions, thus suggesting broad support for the Dole spending test. Also note that Justice Rehnquist was the author of several federalism decisions that have greatly constricted federal power, including Florida Prepaid Post Secondary Educational Expense Board v. College Savings Bank, 527 U.S. 627 (1999), and United States v. Lopez, 514 U.S. 549 (1995).

177. See Alden v. Maine, 527 U.S. 706, 755 (1999) (noting that "the Federal Government [does not] lack the authority or means to seek the States' voluntary consent to private suits"); New York v. United States, 505 U.S. at 145 ("As relevant here, Congress may, under its spending 
guarantee these Justices would vote as predicted, a majority of the Justices likely would uphold the test.

Even if the Court decided to put more bite in the coercion requirement, this scheme still would likely pass scrutiny. Although a state would have to forgo protection for all of its own intellectual property, it is unlikely that would constitute a serious act of coercion of the state. Intellectual property rights owned by a state generate significant revenue, but taking them away would not prevent the state from obtaining revenue from other sources, such as increased taxation. The Court dismissed the $\$ 100$ million condition in South Dakota v. Dole without much discussion. ${ }^{178}$ Also, the federal government voluntarily forgoes copyright protection for works produced by federal employees in the scope of their employment, ${ }^{179}$ and it has not experienced visibly harsh economic side effects as a result.

A well-respected federalism scholar has recently written an article arguing that "the spending power is different and should not be constrained by the Tenth or Eleventh Amendment or construed narrowly as the Court has done with the commerce power and section 5 of the Fourteenth Amendment." ${ }^{180} \mathrm{He}$ further distinguishes the other federalism cases by noting that:

$[\mathrm{N}] \mathrm{o}$ limits on the scope of the spending power can be reasonably inferred from the text of the Constitution. The commerce power limits Congress to regulating commerce "among the states" and section 5 of the Fourteenth Amendment constricts Congress to adopting laws "to enforce" that amendment.... Quite the contrary, the spending power authorizes Congress to tax and spend to "provide for the common Defence and general Welfare of the United States." It is hard to imagine a broader statement of the scope of Congress' power. $^{181}$

\footnotetext{
power, attach conditions on the receipt of federal funds, so long as such conditions meet four requirements."); see also Proctor, supra note 76, at 470 (quoting Justice O'Connor in New York v. United States as noting that "short of outright coercion ... Congress may urge a State to adopt a legislative program consistent with federal interests" in suggesting that the Brady Act might be saved by conditioning federal grants on state compliance).

178. Dole, 483 U.S. at 211.

179. 17 U.S.C. $\$ 105$ (1994).

180. Erwin Chemerinsky, Protecting the Spending Power, 4 CHAP. L. REV. 89, 90 (2001).

181. Id. at 93. In providing further support for his thesis, Chemerinsky also cites National Endowment for the Arts v. Finley, 524 U.S. 569, 588 (1998), and Rust v. Sullivan, 500 U.S. 173, 193-94 (1991), as cases in other contexts in which the Court has "consistently reaffirmed the power of the federal government to choose what to fund by placing conditions on the money." Chemerinsky, supra note 180, at 96-97. In Finley, the Court held that the National Endowment
} 
In a way, the Spending Clause is enticing for even the most ardent states' rights supporters. It gives Congress a chance to legislate on important issues without compromising the states' integrity; it does not compel any state action. Such a scheme gives the states a choice to perform some action in return for some gift or gratuity. States retain their sovereign right to make agreements with other sovereigns; they are "equal partners in a freely bargained relationship." 182 Ultimately, "conditioning federal funds on an explicit state waiver of sovereign immunity does not violate bedrock principles of federalism."183

The conditional waiver scheme is the logical continuation of a line of cases granting Congress broad power to set conditions for states to receive certain gratuities. No precedent suggests this scheme would be interpreted any differently. Congress has the authority to induce states to waive their sovereign immunity in federal court. Intellectual property rights are "gratuities" to the state, because they are not mandated by the Constitution. Therefore, Congress has the power to make the receipt of federal intellectual property protection contingent upon states' waiving their immunity in such cases.

2. Condition Federal Funds on States' Waiving their Sovereign Immunity. Congress has the option of conditioning federal funds on states' waiving their sovereign immunity in federal court. This option is based on Congress's power under the Spending Clause, and operates in a fashion similar to the option described in Part III.B.1. Instead of conditioning federal participation in the federal intellectual property system on states' waiving their immunity in federal court, Congress would condition federal funding that relates to intellectual property.

Although a conditional funding plan would be constitutional, it may be less effective than a conditional waiver bill because of the relatedness requirement. The Register of Copyrights noted that copyrights, patents, and trademarks do not relate as easily to federal spending as driving and highway funds. ${ }^{184}$ Congress could condition

\footnotetext{
for the Arts could consider decency and values in screening which pieces of art to fund. 524 U.S. at 588. In Rust, the Court held that Congress constitutionally could condition federal funds on Planned Parenthood's not providing any information about abortion or referring patients to doctors for abortions. 500 U.S. at 193-94.

182. Maltz, supra note 170 , at 112.

183. Sandoval v. Hagan, 197 F.3d 484, 494 (11th Cir. 1999).

184. Hearings on State Sovereign Immunity, supra note 4, at 25 \& n.64 (statement of Marybeth Peters).
} 
federal funds for state universities on their waiver of their right to immunity from suit. State universities have been one of the main sources of private intellectual property infringement. However, tying a waiver of immunity to federal spending for higher education is problematic; there would be political tensions and such a system could wind up unfairly penalizing institutions of higher learning if their state legislatures refuse to waive their immunity. ${ }^{185}$ It also would cover only some of the states' infringements; many victims would be left unprotected.

The relatedness requirement also may create difficulties in its implementation. A conditional scenario based on federal funding would raise questions, such as: "[C]an Congress condition the grant of funds for scientific research on waiver for suit for all intellectual property claims or just ones stemming from patent?"186 Still, another disadvantage is that this option may require a congressional appropriations committee to reenact this legislation every year. ${ }^{187}$

Overall, although this method certainly has promise, the conditional gratuity plan probably would be more effective at obtaining proper remedies for victims of state intellectual property infringement. ${ }^{188}$ Other options Congress may consider are even less effective, however, and may be unconstitutional as well.

\footnotetext{
185. Id. at 25 .

186. Ghosh, supra note 60 , at 658 .

187. Hearings on State Sovereign Immunity, supra note 4, at 25 (statement of Marybeth Peters).

188. One commentator suggests another approach to sidestepping the Florida Prepaid and College Savings Bank decisions. The approach would work as follows: "Congress merely refuses to recognize future state intellectual property rights until such time as that particular state waives its sovereign immunity to suit for intellectual right infringement." O'Connor, supra note 60 , at 1041 . The major difference between this proposal and the conditional gratuity scheme is procedural. While the conditional gratuity scheme would have states "opting into" the federal intellectual property program and consequences ensuing if they claim immunity in any infringement suits, the quid pro quo solution would have Congress merely refusing to recognize any future rights if the state does not waive its immunity.

There are several reasons why the conditional gratuity plan is superior. The link between the quid pro quo scheme and the Spending Clause cases is more tenuous. The author of this scheme says it "depends on the unique features of the intellectual property system, and the fact that both states and private citizens are participants in the federal intellectual property system." Id. at 1040. The conditional gratuity plan also is more extensive than O'Connor's scheme and would provide more effective protection and remedies for victims of intellectual property right infringement.
} 


\section{Unsatisfactory Proposals to Remedy State Immunity}

Congress could consider several other options not based on the Spending Clause: (1) pass a constitutional amendment; (2) amend the intellectual property acts to permit suits against states in state courts; (3) empower a federal agency to bring actions against states for violating the intellectual property rights of private parties; or (4) enact more narrowly tailored legislation under Section 5 of the Fourteenth Amendment. However, as this Note demonstrates, none of these possibilities will both adequately protect the interests of victims of stateactor infringement and pass constitutional muster with the present Supreme Court.

1. Pass a Constitutional Amendment to Make States Liable for Infringement. Senator Arlen Specter, a Republican from Pennsylvania, has suggested that "a constitutional amendment is the only way to reinstate the balance between the authority of the Congress and the usurpation by the Supreme Court." ${ }^{\text {189 }}$ The Senator rejects the possibility that Congress could adopt legislation that would pass the City of Boerne test for legislation enacted under Section 5 of the Fourteenth Amendment. ${ }^{190}$ Although it may be true that Congress will not be able to tailor legislation to fit the City of Boerne test, Senator Specter probably did not give enough consideration to other possibilities Congress could consider. Constitutional amendments are extremely difficult to pass in the United States. ${ }^{191}$ Even if Congress approves a new amendment, three-fourths of the states must ratify it. ${ }^{192}$ Therefore, the states remain largely in control of the amendment process, ${ }^{193}$ and they are no more likely to support an amendment than waive their sovereign immunity.

189. 149 CONG. REC. S10361 (daily ed. Aug. 5, 1999) (statement of Sen. Specter).

190. See id. ("Given the intensity of the Court's agenda and its inventive and extreme rationales for declaring Congressional actions unconstitutional, it is highly doubtful that anything the Congress does will satisfy the Court in its current campaign.").

191. See, e.g., Henry Paul Monaghan, We the People[s], Original Understanding and Constitutional Amendment, 96 CoLUM. L. REV. 121, 144 (1996) (noting that, although it is less rigid than the amendment system under the Articles of Confederation, the Framers intentionally created a very difficult process).

192. U.S. CONST. art. V.

193. Elai Katz, On Amending Constitutions: The Legality and Legitimacy of Constitutional Entrenchment, 29 COLUM. J.L. \& SoC. ProBS. 251, 258-59 (1996) ("[T]he American model requires that the states, rather than the national legislature or the American people as a nation, must ultimately agree to a modification of the [Constitution]."). 
2. Amend the Intellectual Property Acts to Permit Suits Against States in State Courts. One option the Copyright Office considered in response to the Florida Prepaid and College Savings Bank decisions was to amend 28 U.S.C. $\S 1338$ (a) to permit suits against states in their own courts. ${ }^{194}$ However, patent and copyright infringements are exclusively federal causes of action, and trademark infringement is substantially federal; therefore, barring individuals from suing the state in federal court is virtually a bar to any relief at all and contravenes the intent of Congress. Contrary to the Supreme Court's reasoning in Florida Prepaid, ${ }^{195}$ Congress found that state remedies were largely inadequate to deal with intellectual property infringement. ${ }^{196}$ In fact, the Copyright Act and Patent Act largely preempt state remedies. ${ }^{197}$ Generally, state remedies are considerably weaker than the remedies provided for in federal statutes.

Furthermore, this option seems like a clear non-starter after the Supreme Court's decision in Alden v. Maine, ${ }^{198}$ holding that a state's right to claim sovereign immunity in state court is effectively equivalent to its right to claim immunity in federal court. ${ }^{199}$ Permitting suits in state courts would be viable only if the states voluntarily waive their immunity in state courts. Thus, permitting suits in state courts appears to be no more effective than inaction. The federal government has no more leverage to make the states receptive to suit in state courts than in federal courts, and all things being equal, federal

194. Hearings on State Sovereign Immunity, supra note 4, at 24 (statement of Marybeth Peters). The district courts have original jurisdiction in civil actions relating to federal patent, plant variety protection, copyright, and trademark law, and their jurisdiction is exclusive in the case of patent, plant variety protection, and copyright cases. 28 U.S.C. $\$ 1338$ (a) (1994).

195. See Fla. Prepaid Postsecondary Educ. Expense Bd. v. Coll. Sav. Bank, 527 U.S. 627, 628 (1999) (finding that Congress did not sufficiently consider whether the state remedies were constitutionally adequate).

196. See, e.g., H.R. REP. No. 101-960, at 37 (1990) (citing the drawbacks of withdrawing the federal forum for intellectual property actions and of plaintiffs' not receiving any money damages from the states for copyright infringement and concluding that the states' sovereign immunity must be abrogated to ensure infringees received proper remedies).

197. The Copyright Act explicitly preempts state law. 17 U.S.C. $\$ 301$ (1994); see also Hearings on State Sovereign Immunity, supra note 4, at 24 (statement of Marybeth Peters) (noting that copyright law largely preempts state law). Although the Patent Act, 35 U.S.C. $\S 1$ et. seq. (1994), does not contain an explicit preemption provision, courts consistently have held that federal patent law preempts conflicting state law. Bonito Boats, Inc. v. Thundercraft Boats, Inc., 489 U.S. 141, 168 (1989); Compco Corp. v. Day-Brite Lighting, Inc., 376 U.S. 234, 237 (1964); Sears, Roebuck \& Co. v. Stiffel Co., 376 U.S. 225, 231 (1964); Mars, Inc. v. Kabushiki-Kaisha Nippon Conlux, 24 F.3d 1368, 1373 (Fed. Cir. 1994).

198. 527 U.S. 706 (1999).

199. Id. at $709-10$. 
court is the preferred forum for intellectual property suits. Congress gave the federal courts exclusive jurisdiction to hear these suits to promote uniformity and greater expertise in the judiciary with respect to intellectual property law. ${ }^{200}$

3. Empower a Federal Agency to Bring Actions Against States for Violating Intellectual Property Rights of Private Parties. Another option available to Congress to overcome state immunity is to sanction a suit by the United States via a federal agency on behalf of victims of state-actor infringement. ${ }^{201}$ States have no immunity from suit by the United States. ${ }^{202}$ The United States may bring suit to enforce federal law regardless of whether it has a proprietary interest in the outcome. ${ }^{203}$ Congress used a similar approach in, for example, authorizing the Department of Labor to enforce the Fair Labor Standards Act. ${ }^{204}$

However, significant resource problems accompany this method, and there seems to be little advantage to this approach over the current system. Some of the participants in recent congressional hearings expressed doubt whether this scheme would be constitutional, especially in view of the Supreme Court's present stance on states' rights and sovereign immunity. ${ }^{205}$ Even though a state actor is responsible

200. See 28 U.S.C. $§ 1338$ (1994) (giving district courts original jurisdiction of any civil action arising under any act of Congress relating to patents, plant variety protection, copyrights, and trademarks); see also Ghosh, supra note 60, at 653 ("The chief problem with creating concurrent jurisdiction is uniformity of law.").

201. Hearings on State Sovereign Immunity, supra note 4, at 25 (statement of Marybeth Peters).

202. See Seminole Tribe v. Florida, 517 U.S. 44, 71 n.14 (1996) (noting this lack of immunity as a method of ensuring a state's compliance with federal law); United States v. Mississippi, 380 U.S. 128, 140 (1965) ("While [the Eleventh Amendment] has been read to bar a suit by a State's own citizen ... nothing in this or any other provision of the Constitution prevents or has ever been seriously supposed to prevent a State's being sued by the United States."); United States v. Texas, 143 U.S. 621, 644-45 (1892) (finding the absence of state immunity to suit by the United States necessary to the "permanence of the Union").

203. See United States v. Raines, 362 U.S. 17, 27 (1960) (holding that Congress may authorize the United States to sue to enforce constitutional provisions); see also United States v. California, 297 U.S. 175, 180 (1936) (discussing the authority of the United States to sue a state under the Federal Safety Appliance Act in order to collect a civil penalty).

204. Hearings on State Sovereign Immunity, supra note 4, at 46 (statement of Daniel J. Meltzer).

205. See id. at 26 (statement of Marybeth Peters) ("It is uncertain whether the Federal Government could succeed in championing the cases of individuals where states could not. However, these decisions cast serious doubt on the constitutionality of this option."); id. at 46 (statement of Daniel J. Meltzer). 
for violating federal law, the Court and Congress may find this to be an insufficient justification for public enforcement. ${ }^{206}$ Furthermore, agencies usually have to get their funding renewed every year, ${ }^{207}$ and the funding would have to be considerable for the federal government to initiate a large number of lawsuits.

The Register of Copyrights also has expressed concerns about the efficacy of this method over simple Ex Parte Young suits brought by individual infringement victims: "Unless a structure can be devised whereby the federal agency can obtain damages for past infringements and turn them over to copyright owners, it is difficult to see any advantage to enforcement by a federal agency that cannot already be obtained under Ex Parte Young." ${ }^{208}$ In congressional hearings, the Register mentioned that this method might have been possible in the form of qui tam suits, where an individual is authorized to pursue a right of action of the federal government. ${ }^{209}$ However, the Supreme Court has recently expressed the notion that the Eleventh Amendment may bar qui tam suits against states. ${ }^{210}$ Justice Scalia noted that the majority has "serious doubt" about the constitutionality of qui tam suits against states in federal courts. ${ }^{211}$

4. Enact More Narrowly Tailored Legislation Under Section 5 of the Fourteenth Amendment. Congress still retains the power to abrogate state sovereign immunity by using Section 5 of the Fourteenth Amendment. ${ }^{212}$ However, the test for abrogating state immunity in

\footnotetext{
206. Id. at 46 (statement of Daniel J. Meltzer).

207. Id.

208. Id. at 25 (statement of Marybeth Peters).

209. Id.

210. See Vt. Agency of Natural Res. v. United States ex rel. Stevens, 529 U.S. 765, 787 (2000) (holding that the False Claims Act (FCA) did not subject a state to qui tam liability, because the term "person" in the FCA did not include states for the purposes of qui tam liability).

211. Id. at 787.

212. See Fla. Prepaid Postsecondary Educ. Expense Bd. v. Coll. Sav. Bank, 527 U.S. 627, 636-37 (1999) (“"[A]ppropriate legislation pursuant to the Enforcement Clause of the Fourteenth Amendment [can] abrogate state sovereignty."); Seminole Tribe v. Florida, 517 U.S. 44, 74 (1996) ("[W]here Congress has prescribed a detailed remedial scheme for the enforcement against a State of a statutorily created right, a court should hesitate before casting aside those limitations and permitting an action against a staff officer ...."); Fitzpatrick v. Bitzer, 427 U.S. 445, 456 (1976) ("Congress may, in determining what is 'appropriate legislation' for the purpose of enforcing the provisions of the Fourteenth Amendment, provide for private suits against States or State officials which are constitutionally impermissible in other contexts.").

Early cases made it clear that the Fourteenth Amendment was intended to be a direct limitation on the states' power. See Ex Parte Virginia, 100 U.S. 339, 346 (1879). The Supreme
} 
this manner is very rigid under City of Boerne v. Flores. ${ }^{213}$ To determine whether an act is constitutional under this test, one should ask whether there is "a congruence and proportionality between the injury to be prevented or remedied and the means adopted to that end." ${ }^{214}$ This decision drastically contracted Congress's power under Section 5 of the Fourteenth Amendment. ${ }^{215}$ The Court maintained that these limitations on the Fourteenth Amendment are necessary to prevent it "from obliterating the Framers' carefully crafted balance of power between the States and the National Government.",216

In fact, the Supreme Court has struck down legislation in every case in which it has applied the City of Boerne test since the decision was handed down. For instance, in Kimel v. Florida Board of Regents ${ }^{217}$ the Supreme Court held that Congress exceeded its authority under Section 5 of the Fourteenth Amendment when it attempted to abrogate the states' immunity in Age Discrimination in Employment Act suits. ${ }^{218}$ Federal courts of appeals have been similarly reticent about permitting congressional abrogation of state sovereign immunity. They have invalidated abrogation attempts under the Copyright Act, ${ }^{219}$ the Americans with Disabilities Act, ${ }^{220}$ the Fam-

Court pronounced in this case that the contemplated federal "legislation is restrictive of what the State might have done before the constitutional amendment was adopted." Id. Because the Fourteenth Amendment was intended to confine the states' powers, Congress may constitutionally abrogate state sovereign immunity under this amendment.

213. 521 U.S. 507, 517 (1997); see also supra note 18 and accompanying text.

214. City of Boerne, 521 U.S. at 520.

215. Rachel Toker, Tying the Hands of Congress-City of Boerne v. Flores, 33 HARV. C.R.C.L. L. REV. 273, 273 (1998).

216. United States v. Morrison, 529 U.S. 598, 620 (2000).

217. 528 U.S. 62 (2000).

218. Id. at 91; see also Bd. of Trustees of the Univ. of Ala. v. Garrett, 531 U.S. 356, 373 (2001) (holding Congress exceeded its authority under Section 5 of the Fourteenth Amendment by abrogating the states' immunity from suits under the Americans with Disabilities Act).

219. See, e.g., Chavez v. Arte Publico Press, 204 F.3d 601, 608 (5th Cir. 2000) (holding that the statutory abrogation of a state's immunity—allowing an author to seek damages for alleged copyright infringement-was not a proper exercise of Congress's power to enforce the Fourteenth Amendment's Privileges and Immunities Clause).

220. See, e.g., Neinast v. Texas, 217 F.3d 275, 282 (5th Cir. 2000) (holding that a federal regulation promulgated pursuant to the ADA, which prohibited Texas from imposing a fee for handicapped parking placards, did not validly abrogate the state's immunity from suit under the Eleventh Amendment); Stevens v. Ill. Dep't of Transp., 210 F.3d 732, 741 (7th Cir. 2000) (holding that the Illinois Department of Transportation is immune to suit brought by an individual under the ADA). 
ily Medical Leave Act of $1993,{ }^{221}$ and various environmental statutes. ${ }^{222}$

In Florida Prepaid, the Supreme Court held that the Patent Remedy Act was not properly enacted under Section 5 of the Fourteenth Amendment. ${ }^{223}$ The Court held that the Act, by permitting a federal patent infringement remedy without regard to the existence of an adequate state post-deprivation remedy, did not respond to a constitutional violation. ${ }^{224}$ The Court continued by noting that, "[i]nstead, Congress appears to have enacted this legislation in response to a handful of instances of state patent infringement that do not necessarily violate the Constitution.",225

Professor Shubha Ghosh asserts that a Section 5 solution "is very powerful and will undoubtedly be the source for Congress' attempt to statutorily reverse the Court's decision in [Florida Prepaid].,"226 Although theoretically possible, it would be extremely difficult for Congress to tailor the Patent Remedy Act narrowly enough to pass the Court's "congruence and proportionality" test for the same reasons that the Florida Prepaid Court struck down the Act in the first place. $^{227}$

Congress would have to establish a much more extensive record of state-actor infringement than what it presented to the Florida Prepaid Court to establish that Congress was attempting to remedy widespread constitutional violations. A constitutional violation occurs only when a state provides inadequate or no remedies when it infringes on a property owner's rights without due process. The Florida Prepaid Court was dissatisfied with the record Congress compiled during the

221. See, e.g., Chittister v. Dep't of Cmty. \& Econ. Dev., 226 F.3d 223, 229 (3d Cir. 2000) (stating that "the FMLA [Family Medical Leave Act] provisions at issue here do not represent a valid exercise of Congress's power to enforce the Fourteenth Amendment and that the FMLA does not abrogate Eleventh Amendment immunity").

222. See, e.g., Burnette v. Carothers, 192 F.3d 52, 57 (2d Cir. 1999) (holding that the citizen suit provisions of the Clean Water Act, the Resource Conservation and Recovery Act, and the Comprehensive Environmental Response, Compensation, and Liability Act did not abrogate state sovereign immunity under the Eleventh Amendment, but rather were expressly limited by it).

223. Fla. Prepaid Postsecondary Educ. Expense Bd. v. Coll. Sav. Bank, 527 U.S. 627, 647 (1999). For a longer description of the holding of Florida Prepaid, see supra notes 26-40 and accompanying text.

224. Id. at $645-46$.

225. Id.

226. Ghosh, supra note 60 , at 659 .

227. See supra notes $35-40$ and accompanying text. 
passage of the Patent Remedy Act, ${ }^{228}$ and that probably would not change unless many state immunity claims were suddenly raised to create such a record.

Also, it is worth noting that extensive findings in and of themselves will not sustain legislation under Section 5 of the Fourteenth Amendment. For example, in United States v. Morrison, ${ }^{229}$ the $\mathrm{Su}-$ preme Court struck down portions of the Violence Against Women Act (VAWA) despite admitting that the Section 5 claim was "supported by a voluminous congressional record."230 Although some would agree that a constitutional violation has been established when states infringe on intellectual property rights, the Supreme Court disagrees, and there is no reason to believe it will change that perception in the foreseeable future.

Even if Congress could tailor legislation narrowly enough to satisfy the test, the legislation most likely would be too weak to provide an adequate remedy to victims of state-actor infringement. The legislation would have to be directed at situations in which an adequate state remedy does not exist or is highly questionable, and Congress would have to make extensive findings to that effect. ${ }^{231}$ Professor Meltzer, in his testimony before Congress, suggested that Congress could provide a cause of action against states that intentionally deprive individuals of their intellectual property rights when the state does not provide an adequate remedy. ${ }^{232}$ Under this scheme, when a state actor intentionally infringes a person or entity's intellectual property rights, the victim could sue the state or its officials in state court if the remedy is adequate; if it is not adequate, the party could allege a constitutional violation and bring a suit in federal court under this statute. ${ }^{233}$

There are several problems with this scheme from the perspective of the infringement victim, however. Many state-actor infringements are not intentional and therefore not covered by the statute.

\footnotetext{
228. Fla. Prepaid, 527 U.S. at 640.

229. 529 U.S. 598 (2000).

230. Id. at 620 .

231. Language in Senate Bill 1835, see supra note 8, has attempted to tailor the legislation extremely narrowly to fit the parameters of the Supreme Court's jurisprudence. However, for reasons discussed in the remainder of this Note, such a bill would not be effective at protecting victims of state-actor intellectual property infringement.

232. Hearings on State Sovereign Immunity, supra note 4, at 40 (statement of Daniel J. Meltzer).

233. Id.
} 
Also, the definition of "intentional" in the case law is unclear. ${ }^{234}$ Furthermore, many states do not provide adequate causes of action for victims of state-actor infringement. Intellectual property rights have been a purely federal cause of action, and few state laws cover this kind of harm. ${ }^{235}$

The Court has not even expressly established what kind of remedy is "adequate" for the purposes of the Fourteenth Amendment. ${ }^{236}$ A state must violate the Fourteenth Amendment for Congress to be able to use its enforcement power. The state must either provide no remedy or a constitutionally "inadequate" remedy to infringement victims for it to be a violation of the Due Process Clause of the Fourteenth Amendment. ${ }^{237}$ The Court in Florida Prepaid did not specifically discuss what would constitute an "adequate" state remedy.

The Supreme Court generally treats "adequacy" as a constitutional standard, and the Constitution does not seem to require as expansive a remedy as that provided by the federal intellectual property statutes. ${ }^{238}$ An "adequate" remedy may include only a rehearing before some authority that can provide redress, ${ }^{239}$ and a remedy may be "adequate" even if it provides no punitive damages or attorney's fees. ${ }^{240}$ The courts have split over whether providing only for injunctive relief is "adequate. ${ }^{, 21}$ Whatever the exact standard by which an

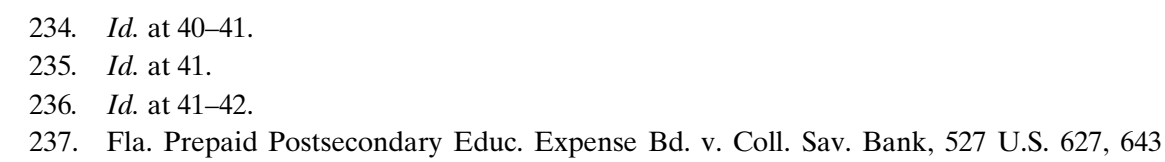
(1999); Hudson v. Palmer, 468 U.S. 517, 532-33 (1984); see also Parratt v. Taylor, 451 U.S. 527, 541 (1981) (noting that the state cannot take property without providing a "meaningful" postdeprivation hearing but that "prior cases have excused a prior-hearing requirement on the availability of some meaningful opportunity subsequent to the initial taking" to determine rights and liabilities).

238. Hearings on State Sovereign Immunity, supra note 4, at 42 (statement of Daniel J. Meltzer) (citing Parratt, 451 U.S. at 543-44).

239. Williams v. St. Louis County, 812 F.2d 1079, 1082 (8th Cir. 1987).

240. See Parratt, 451 U.S. at 543-44 ("Although the state remedies may not provide the respondent with all the relief which may have been available if he could have proceeded under $\S 1983$, that does not mean that the state remedies are not adequate to satisfy the requirements of due process."). Note that the federal intellectual property laws do provide for full costs and attorney's fees and treble damages in some situations. See, e.g., 17 U.S.C. $\$ 505$ (1994) (providing for full costs and attorney's fees in copyright infringement actions); 35 U.S.C. $\S \S 283-285$ (1994) (providing for injunctive relief, treble damages, and attorney's fees in patent infringement actions); see also Oiness v. Walgreen Co., 774 F. Supp. 1277, 1286 (D. Colo. 1991) ("As with trebled damages, an award of attorney fees is within the discretion of the court.").

241. Compare Rittenhouse v. DeKalb County, 764 F.2d 1451, 1459 (11th Cir. 1985) (holding that state remedies that completely bar any prospect of monetary recovery because of sovereign 
"adequate" remedy is to be measured, it very likely would be far less generous to a victim of infringement than the federal statutory remedy would be.

Even if states did provide an adequate cause of action, enforcing intellectual property laws at the state level would undermine key aspects of the federal intellectual property system. The enforcement of intellectual property rights is best achieved if its application is uniform, and state court judges are not experts on these issues. To further this uniformity and judicial expertise, Congress created a single court of appeals for patent cases, the Federal Circuit. ${ }^{242}$

Enacting legislation under the Fourteenth Amendment would encounter the additional problem of ascertaining exactly what kinds of intellectual property rights are property in the constitutional sense. Patents are considered property, ${ }^{243}$ and trade secrets are also generally considered property within the meaning of the Fifth and presumably the Fourteenth Amendments. ${ }^{244}$ In College Savings Bank, ${ }^{245}$ the Supreme Court held that rights against false advertising do not constitute property. ${ }^{246}$ The status of other types of intellectual property is unclear.

One additional problem with an abrogation statute of this kind is that Congress probably cannot identify a widespread pattern of constitutional violations by the states. ${ }^{247}$ In Florida Prepaid, the Court failed to find such a pattern. However, Professor Daniel J. Meltzer explained to Congress his belief that this problem does not necessarily doom this hypothetical statute because this "measure is more easily viewed as 'remedial,' and the validity of a statute limited to regu-

immunity are adequate), with Roy v. City of Augusta, 712 F.2d 1517, 1523 n.6 (1st Cir. 1983) (holding that such a remedy is not adequate).

242. See 28 U.S.C. $\$ 1295$ (1994) (stating that the Federal Circuit has exclusive jurisdiction over appeals from the district court level arising under the federal patent statute).

243. See Fla. Prepaid Postsecondary Educ. Expense Bd. v. Coll. Sav. Bank, 527 U.S. 627, 642 (1999) ("[P]atents may be considered 'property' for purposes of our analysis . ..."); Brown v. Duchesne, 60 U.S. (19 How.) 183, 197 (1856) ("For, by the laws of the United States, the rights of a party under a patent are his private property ....”).

244. See Ruckelshaus v. Monsanto Co., 467 U.S. 986, 1003-04 (1984) (holding that trade secrets, though intangible, have characteristics of more traditional forms of property and are therefore protected by the Takings Clause of the Fifth Amendment).

245. Coll. Sav. Bank v. Fla. Prepaid Postsecondary Educ. Expense Bd., 527 U.S. 666 (1999).

246. Id. at 670-72.

247. See Kimel v. Fla. Bd. of Regents, 528 U.S. 62, 90-91 (2000) ("[I]t is sufficient for the cases to note that Congress failed to identify a widespread pattern of age discrimination by the States.”); Fla. Prepaid, 527 U.S. at 644 ("“[T]he availability of a State remedy is tenuous and could vary significantly State to State.”') (quoting H.R. REP. No. 101-960, at 37 n. 158 (1990)). 
lating unconstitutional conduct itself should not require an additional showing of widespread violations by the states." 248

The most important consideration in assessing enforcement powers under the Fourteenth Amendment does seem to be whether the measure is remedial. However, the Court repeatedly has asked whether there is a widespread pattern of constitutional violations in determining whether legislation enacted under Section 5 is congruent and proportional, including in Florida Prepaid. ${ }^{249}$ Although looking for a pattern of constitutional violations may not entail a rigid analysis that needs to be satisfied separately from the "congruence and proportionality" test, it provides important insight into what the Court will require to meet the test. It does not appear likely that the Patent Remedy Act, even if amended, could pass this examination.

Another attempt by Congress to abrogate state sovereign immunity using Section 5 of the Fourteenth Amendment would probably prove to be futile, at least in the immediate future. Even if Congress could draft legislation to surmount the hurdles established in these cases, it most likely would be unsuccessful at obtaining for victims of intellectual property infringement the remedies they deserve.

\section{CONCLUSION}

Congress should adopt the conditional waiver plan advocated by this Note to circumvent the Supreme Court's decisions in Florida Prepaid and College Savings Bank. Although there may be legitimate reasons for the states to have immunity from suit in certain contexts, state immunity serves no compelling interest in intellectual property infringement suits. The states' interest in sovereign immunity seems meager compared to the interests of the victims with no suitable remedy. Inverse condemnation and Ex Parte Young suits provide inadequate remedies for infringement claimants, and the present system is unlikely to be altered by a constitutional amendment.

248. Hearings on State Sovereign Immunity, supra note 4, at 43 (statement of Daniel J. Meltzer).

249. See Fla. Prepaid, 527 U.S. at 645 ("The legislative record thus suggests that the Patent Remedy Act does not respond to a history of "widespread and persisting deprivation of constitutional rights' of the sort Congress has faced in enacting proper prophylactic $\S 5$ legislation.") (citing City of Boerne v. Flores, 521 U.S. 507, 526 (1997)); see also Kimel, 528 U.S. at 91 ("Congress' failure to uncover any significant pattern of unconstitutional discrimination here confirms that Congress had no reason to believe that broad prophylactic legislation was necessary in this field."). 
It seems highly improbable Congress will be able to pass legislation under Section 5 of the Fourteenth Amendment after the virtually insurmountable test announced in City of Boerne. Even if it could, the legislation probably would be too diluted to be effective. Empowering a federal agency to sue states for intellectual property infringement is of dubious constitutionality and efficacy, and amending the intellectual property acts to permit suits against states in state courts appears similarly unlikely to be effective in obtaining suitable remedies for victims of state-actor intellectual property infringement.

The best solution is to condition the gratuity of participation in the federal intellectual property system on states' waiving their immunity in the traditional federal court forum. There is a strong body of case law to suggest this approach would pass constitutional muster, even with the current Supreme Court Justices, and it would be very effective at obtaining extensive remedies for the infringement victims. It also has the added policy benefit of saving face both for the states and for the Supreme Court. It allows the federal government to legislate on this very important issue without diverging from precedent or intruding unnecessarily on the power of the state governments. 